${ }^{\circ}$ Copyright by Pusat Riset dan Pengembangan Produk Halal Universitas Airlangga

\title{
REGULATORY FRAMEWORK FOR ISLAMIC FINANCIAL INSTITUTIONS: LESSON LEARNT BETWEEN MALAYSIA AND INDONESIA
}

\author{
KERANGKA REGULASI LEMBAGA KEUANGAN ISLAM: \\ STUDI ANTARA MALAYSIA DAN INDONESIA
}

\author{
Fazlurrahman Syarif \\ MBA Islamic Banking and Finance, Bangor University \\ Bangor LL57 2DG, United Kingdom \\ *Email : fazlursyarif@yahoo.com
}

\begin{abstract}
Islamic finance is a rapidly growing stream in the Halal economy. Islamic finance is a method of banking or financing activities that are based on the Sharia law and operated by sharing the risk or divide the profits of any investment as per the agreed terms. This study discusses the forms of a regulatory framework and on the organisations that are constituted for standardising the regulations. The paper also analyses the regulatory framework for Islamic financial institutions in Malaysia and Indonesia. The type of research used is a descriptive qualitative model. We find that both the countries maintain a dual system of the regulatory framework which considers the conventional and Islamic financial system. Hence, the central bank has full authority to enact required laws and policy and to regulate the Islamic financial institutions in Indonesia and Malaysia.
\end{abstract}

Keywords: Islamic Finance, Regulatory Framework, Sharia Law

\section{ABSTRAK}

Keuangan Islam kini mengalami perkembangan pesat di industri halal. Keuangan Islam merupakan kegiatan yang didasarkan pada hukum Syariah dan dioperasikan dengan berbagi risiko atau berbagi keuntungan dari investasi apapun sesuai dengan ketentuan yang disepakati. Penelitian ini membahas bentuk kerangka peraturan dan organisasi-organisasi, yang berperan untuk standardisasi aturanaturan. Tulisan ini juga menganalisis kerangka peraturan untuk lembaga keuangan Islam di Malaysia dan Indonesia. Jenis penelitian yang digunakan adalah model deskriptif kualitatif. Kami menemukan bahwa kedua negara menganut dual system yaitu sistem keuangan konvensional dan syariah. Oleh karena itu, bank sentral memiliki kewenangan penuh untuk membuat undang-undang dan kebijakan yang diperlukan dan untuk mengatur lembaga keuangan Islam di Indonesia dan Malaysia.

Kata Kunci: Keuangan Islam, Kerangka Regulasi, Hukum Syariah

\section{INTRODUCTION}

Islamic finance is a rapidly growing concept in the modern world and is a process of banking or financing activities which is based on ethical and religious principles. Islamic finance or banking can be termed as interest-free banking. Islamic financial institutions are those financial institutions which operates according to the Sharia principles (Ayub, 2007). The legal and regulatory framework for a financial institution regulates the operations of the institutions and helps to achieve the objectives. The regulatory framework for the financial institutions are significant for improving efficiency, increasing stability, lessening risk and promoting economic development (Ginena and Hamid, 2015). The acceptance of the Islamic finance internationally required the countries to enact legal and regulatory framework for the better operation of the Islamic institutions. The Islamic financial institutions are based on the Sharia principles and domestic law (common law or civil law) shall not be able to regulate the Islamic financial institutions effectively. The Islamic financial institutions in a country may be governed either solely by enacted provisions based on Sharia law or the existing 
domestic law has adopted to needs of Islamic financial institutions. Many countries have adopted the regulatory framework for Islamic finance with international standards which are capable of substituting the conventional framework.

\section{REGULATORY FRAMEWORK FOR ISLAMIC FINANCIAL INSTITUTIONS}

The regulatory framework for the Islamic financial institutions can be termed as the Sharia governance framework which regulate and supervise the Islamic financial institutions to ensure the compliance of Sharia law in all its operations (Elasrag 2014). The regulatory framework for the Islamic financial institutions can be classified mainly into three forms: Fully Islamic, Dual Systems and Neutral or partial inclusion. Fully Islamic means those countries only accept banking and financial institutions which are based on Sharia principles and they prohibit conventional financial institutions. This is mainly adopted in Muslim countries. Pakistan was a country which follows fully Islamic system up to 2001 after that it has permitted conventional banking system in the country. In dual system, the countries allow the conventional finance to operate along with Islamic finance. Example: Bahrain and Malaysia. This system is suitable in a country where there is population of non-Muslim are high.

The dual system targets to increase the market share of Islamic finance. Neutral system maintains fair and unbiased nature; it does not favour the Islamic finance (Kepli and Yazid 2013). Development of Islamic financial industry made it necessary for the countries to enact rules and regulations to govern the finance industry. Introduction of various products through the Islamic financial institutions it became necessary to analyse whether products are in compliant with Sharia principles or not. Thus, it led to the development Sharia boards within the institutions for evaluating the products. To standardize the norms of Sharia principles, different organisations were established to develop international standards and guidelines. The organisations are Accounting and Auditing Organization for Islamic Financial Institutions (AAOIFI), Islamic Financial Services Board (IFSB), International Islamic Liquidity Management Corp (IILM), Islamic International Rating Agency (IIRA), and International Islamic Financial Market (IIFM) (Elasrag 2014).

Sharia Board, a committee of Islamic scholars which verify whether the products of Islamic financial institutions are in compliance with Islamic law or not. Nowadays, it is mandatory to constitute a Sharia board in many countries as per the provisions of law. AAOIFI standards define the duty of Sharia board and the AAOIFI standards define the procedure for constituting the board. The Accounting and Auditing Organization for Islamic Financial Institutions (AAOIFI) is an independent non-profit organisation established in 1990 to promote and maintain the Sharia standards of Islamic financial institutions. If there are difficulties in relation to new financial products, AAOIFI shall provide guidelines for interpretations and the AAOIFI is focussing on the auditing and accounting area (Kasim et al. 2013) .

For the development of the Islamic financial industry, a regulatory and supervisory framework is required. Islamic Financial Services Board (IFSB) was established in Malaysia 2002. IFSB was developed in connection with the International Monetary Fund and Basel committee on banking supervision. IFBS focus on the standardisation of procedures and interpretation (Elasrag 2014).

International Islamic Financial Market (IIFM) began its operation in 2002 aiming at standardization of Islamic financial products, documentation and allied processes. The main objectives of IIFM are to establish an International financial market grounded on Islamic Sharia, maintain an active secondary market and ensure active participation of Islamic and non-Islamic financial institutions. Malaysia and Indonesia has entered into an agreement to establish IIFM (Elasrag 2014).

The International Islamic Liquidity Management Corporation (IILM) is established by central banks, financial authorities and multilateral organisations to develop and issue financial instruments which are in compliance with Sharia to facilitate cross-border Islamic liquidity management (IILM 2019). Islamic International Rating Agency (IIRA) provides independent assessment to issuers and issues that conform to Islamic finance principles. IIRA focuses on development of capital market and to develop the Islamic finance sector. The IIRA is a facility provider to support Islamic finance and it is supported with AAOIFI and IFSB (Islamic Finance Wiki 2019).

\section{REGULATORY FRAMEWORK IN MALAYSIA}

The development of Islamic banking in Malaysia has different phases. Malaysia has implemented policy which allows the foreign entities to establish banks in local market (Hasan, 2010). The development of the Islamic financial institutions in Malaysia are facilitated and supported by some

\footnotetext{
${ }^{\circ}$ Copyright by Pusat Riset dan Pengembangan Produk Halal Journal of Halal Product and Research
} E-ISSN: 2654-9778; P-ISSN: 2654-9409 
legislations such as Islamic Banking Act 1983 (IBA), the Takaful Act (1984), the Banking and Financial Institutions Act 1989 (BAFIA), the Securities Commission Act 1993, Capital Market and Services Act 2007 (CMSA), the Central Bank of Malaysia Act 2009, and Islamic Financial Services Act 2013 (IFSA) (Hasan 2010). The central bank - Bank Negara Malaysia (BNM), established in 1959 under the Central Bank of Malaysia Act 1958 and the Ministry of Finance regulates the Islamic finance in Malaysia and they are involved in the supervision of Islamic financial activities (Khan et al. 2015). The Central Bank of Malaysia Act 1958 was replaced by Central Bank of Malaysia Act 2009.

In 1980, Bumiputera Economic Congress passed a resolution to allow then Pilgrimage Board to establish an Islamic Bank and participants of seminar in National university also supported the need of special law for Islamic bank. A National Steering Committee on Islamic Banking appointed in 1981 for the feasibility study and government established Bank Islam Malaysia Berhad under Islamic Banking Act 1983 (Siregar 2013). Bank Islam Malaysia Berhad constituted first Sharia board in the same year. Islamic Banking Act 1983 (IBA) was enacted to supervise and control Islamic financial practices and is enforced by separate Sharia boards in both Bank Negara Malaysia and securities commission (Gearen 2009).

The central Bank empowered to supervise and regulate the conventional banking institutions and insurance companies and also the Islamic Banking and Takaful. The Governor of Central Bank is appointed as the Director of General of Takaful with the powers and duties stipulated in Takaful Act of 1984 (Hassana and Hussain 2013).

According to the IBA 1983, every Islamic bank should constitute a Sharia advisory board to ensure that it complies with Sharia principles. In order to standardise the decisions of Sharia advisory bodies, there exist a National Sharia advisory council which advices Bank Negara Malaysia (BNM). Islamic bank is authorised to seek advice of National Sharia Advisory Council on Sharia compliance relating to banking according to IBA 1983 (Kunhibava 2012).

The Government Funding Act 1983 (GFA) permits the Government of Malaysia to issue Government Investment certificates which are securities issued based on Sharia law. The GFA provide option for fund raising by the government using Sharia based investment in securities and Islamic banks are also authorised to invest in Government Investment Certificates to meet liquidity requirements and investing the surplus funds. The Islamic banks, incorporated according to the Companies Act 1965, shall be subject to Islamic Banking Act 1983 and IBA provisions shall prevail in case of any contrary provisions (Alam et al., 2017).

The conventional banks which are licensed under Banking and Financial Institutions Act 1989 (BAFIA 1989) can also engage in banking business upon the approval of BNM. Islamic banking business under BAFIA 1989 has similar meaning of IB Act and the institutions under BAFIA refer the issues to National Sharia Advisory Council to evaluate if there is any violation of Islamic Sharia principles (Kunhibava 2012). National Sharia Advisory Council is the sovereign authority on Islamic banking in Malaysia which was established in 1997 by BNM. The primary aim of the council is to guide and supervise the BNM on banking and insurance and to evaluate the new products and schemes (Kunhibava, 2012). BAFIA 1989 was replaced by Financial Services Act 2013 (FSA) (Bello and Zubaedy 2015).

In 1993, the banks introduced interest free bank scheme and that was the start of competition with conventional system. The conventional banks facilitate Islamic banking services as subsidiary service (Hasan 2010). Securities Commission is self-funding statutory body under Ministry of finance established under the Securities Commission Act 1993. Securities Commission supervise the activities of capital markets institutions or persons licensed under Capital Markets and Services Act 2007. The SC is also responsible to promote and develop the capital markets of Malaysia (Hassana and Hussain 2013).

The Sharia Advisory Council (SCSAC) established under Securities Commission Malaysia Act 1993 assist the Securities Commission to ascertain the application of Sharia principles for the purpose of Islamic Capital market transactions. According to the Capital Market and Services Act, any regulations issued by Securities Commission Sharia Advisory Council shall be binding on the proceedings related to Islamic capital market transactions and the court or arbitrators can execute such rules or regulations. If any rule issued by the SCSAC is contrary to the rulings of registered Sharia advisor on capital market, then the rules issued by SCSAC shall prevail. Securities Commission Sharia Advisory Council issued resolutions complying with Sharia norms on Islamic capital market products in connection with the growth of capital market in Malaysia. In order to compete with the modern trend of e-commerce, Bursa Suq Al Sila was introduced for electronic trading (Sequerah and Hong 2017).

\footnotetext{
${ }^{\circ}$ Copyright by Pusat Riset dan Pengembangan Produk Halal Journal of Halal Product and Research
} E-ISSN: 2654-9778; P-ISSN: 2654-9409 
The Islamic Financial Service Board (IFSB) was established in Malaysia in 2002, an organisation which constituted to promote the soundness and stability of Islamic financial institutions by enacting policies and principles with international standards for the better corporate governance, transparency and risk management (Investopedia, 2019). The Government of Malaysia launched Malaysia International Islamic Financial Center (MIFC) in 2006 with aim to develop the country as Islamic financial hub. The MIFC involves participation of industry players in the field of banking, insurance and securities market in Malaysia (Hassana \& Hussain, 2013). The Capital Market and Services Act 2007 (CMSA) governs the Islamic capital market which is administered by the securities commission in Malaysia. According to the CMS Act, any person legal or natural should have obtained license for dealing in derivatives and securities, fund management, investment advice, corporate finance, etc. CMSA had incorporated provisions related to trading of securities, market misconduct and insider trading (Sequerah and Hong 2017).

Bank Negara Malaysia (BNM) gave more attention on the development of Islamic banking and have developed many plans for the development. Bank Negara Malaysia (BNM) regulates the Islamic Banking in Malaysia and Central Bank Act 2009 was enacted for the same (Siregar 2013). In 2009, the Central Bank of Malaysia Act give more clarity to the functions of National Sharia Advisory Council and according to the Act of 2009 the council is supreme consultant for any issues and questions on Sharia by financial institutions and courts (Kunhibava 2012). In 2011, BNM has developed Sharia Governance Framework for better Sharia governance of Islamic financial institutions in Malaysia. According to the framework, it is the duty of the Islamic financial institutions to establish a comprehensive and strong Sharia governance framework. The framework targets at improve the role of Sharia Advisory Board, Board of Directors and Management in connection with Sharia matters (Kunhibava 2012).

Islamic Financial Services Act (IFSA), which came into force in 2013, governs the Islamic banking and insurance in Malaysia. IBA 1983 was replaced by IFSA 2013. The Act was enacted to ensure the aims and operations and business activities of the licensed institutions are in compliance with the Sharia principles. The Act authorise Bank Negara Malaysia (BNM) to provide the guidelines and standards on Sharia compliance. Sharia Governance Framework for Islamic financial institution was issued by Bank Negara Malaysia (BNM) which guides the Islamic financial institutions and takaful operators to organise its Sharia governance structure (Sequerah and Hong 2017).

IFSA includes similar provisions as in the Financial Services Act (FSA), FSA deliver the regulations and guidelines for financial institutions aiming the financial stability and allied matters. IFSA enable the Islamic financial institutions to compete with the conventional financial institutions in Malaysia (Yussof 2013).

On obtaining a valid license under IFSA, foreign institutions may offer Islamic banking services in Malaysia. In order to operate takaful and retakaful services license under IFSA is mandatory and foreign insurance company can also operate in Malaysia. The central bank and securities commission issue guidelines from time to time specifying specific disclosure or reporting requirements for takaful, sukuk and Islamic funds (Sequerah and Hong 2017).

Labuan Financial Services Authority (LFSA), another regulator for Islamic Financial Institutions, is a corporate body under Labuan Financial Services Authority Act 1996. The aim of LSFA is to develop and administer International Business and Financial Centre and to act as regulatory and supervisory authority of Labuan International Business and Financial Centre. Bursa Malaysia is an exchange holding company under Capital Market and Services Act 2007 which regulates the financial market in Malaysia. Islamic markets offered by Bursa Malaysia including Bursa Suq Al-Sila, Sharia-Compliant Securities, Sukuk, Islamic Real Estate Investment Trust and Sharia Compliant Exchange Traded Funds (Hassana and Hussain 2013).

\section{REGULATORY FRAMEWORK IN INDONESIA}

In Indonesia, the first Islamic bank - Bank Muamalat was established in 1991 and the growth rate of Islamic financial market in Indonesia is high compared to other countries. The dual banking system is followed in Indonesia and was declared by the enactment of Undang-Undang Perbankan Syariah in 2008 (Siregar 2013). The Islamic finance has supported the growth of Indonesian economy. The Ministry of Finance and Financial Service Authority provide opportunity for both the conventional and Islamic financial institutions in the economy (Grant et al. 2017). Prior issuing specific laws for Islamic finance, it was regulated by the conventional financial institutions law. In 2008, the government enacted various law to promote and regulate the Islamic finance market and laws are Law No. 19 of 2008 on Sovereign Sukuk and Law 21 of 2008 on Sharia Banking (Grant et al. 2017).

\footnotetext{
${ }^{\circ}$ Copyright by Pusat Riset dan Pengembangan Produk Halal Journal of Halal Product and Research
} E-ISSN: 2654-9778; P-ISSN: 2654-9409 
The Islamic finance in Indonesia is in developing stage even now. The Bank Muamalat started operation in the year 1992 which is considered as the launch of Islamic finance in Indonesia (Grant et al. 2017). The Law No. 7 of 1992 Banking Act permit the Islamic banks to operate with conventional system and the Act put the foundation for the banking operations in Islamic viewpoint and interest free banking (Furqani 2017).

In 1993, Indonesia initiated the establishment of Islamic Insurance (Takaful) in Indonesia by Indonesian Muslim Scholars Association through Yayasan Abdi Bangsa with Bank Muamalat Indonesia and insurance company Asuransi Tugu Mandiri (Furqani 2017). In 1994, the Bank Muamalat incorporated first takaful operators - PT Asuransi Takaful Keluarga and PT Asuransi Takaful Umum. Law 7 of 1992 on Banking Act was amended in 1998 to permit the conventional banks to provide Sharia banking services. The opening of Sharia based banking in conventional banking sector helps the economy and the amendment helps in survival of 1998 monetary crisis. Law No 8 of 1995 on capital markets which regulates all capital market activities including Islamic capital market activities. The Second bank - Syariah Mandiri, the state-owned bank was established in 1999. The corporate sukuk were listed in 2002, which is the first sukuk in the capital market (Grant et al. 2017).

Zakat Act No. 38 of 1999 regulate Zakat in Indonesia and zakat is managed by government institutions - Badan Amil Zakat and private body - Lembaga Amil Zakat. National Board of Zakat (BAZNAS) supervise all Zakat collectors in Indonesia. Indonesian Waqf Board (Badan Wakaf Indonesia) under Ministry of Religious Affairs supervise Waqf in Indonesia and Waqf Act No. 41 of 2004 regulates the Waqf (Furqani 2017). The Government of Indonesia did feasibility study through Majelis Ulama Indonesia (Indonesia Islamic Scholars Council) to launch the Islamic banks in the country. MUI is only authority for issuing Fatwa in Indonesia. Komisi Fatwa or Fatwa Commission discusses on Fatwa before issuing. Central bank of Indonesia set up Bureau of Sharia Banking Affairs under Directorate of Bank Supervision in 2000 (Siregar 2013).

According to Law No. 40 of 2007 Limited Liability Companies, limited liability companies that engage in Sharia compliant business activities have to constitute a Sharia supervisory board with one Sharia expert to provide advices to company board and supervise the company to make sure that it has complied with Sharia laws (Grant et al. 2017).

Law No 21 of 2008 is the legislation which is applicable to the Islamic Banking. Islamic Banking Act No. 21 of 2008 regulates the Islamic banking in Indonesia and the Act incorporate the provisions of previous regulations and eradicate the irregularities (Furqani 2017). The Act was enacted to develop the Islamic banking and it clearly clarify on the permitted and prohibited operations under Islamic law (Hussain and Williams 2016).

The issuance of sovereign sukuk for deficit financing and infrastructure financing are regulated by Islamic Sovereign Bond (Sukuk) Act No. 19 of 2008 (Furqani, 2017). The regulations issued by the Central bank of Indonesia in 2009 and its amendment in 2013, which allow the foreign share ownership up to $99 \%$ of the paid-up capital of the Sharia banks. Otoritas Jasa Keuangan (OJK) is the sole authority charged with overseeing banking, insurance, capital markets and other nonbanking financial institutions. The new rules issued by OJK intend to promote and regulate growth of Islamic finance. A memorandum of understanding was entered into between OJK and National Sharia Board of Indonesian Ulama Council (DSN-MUI) in 2014 to support the banking sector. The council issues fatwa and evaluate on Sharia compliance (Hussain and Williams 2016).

Law No. 40 of 2014 on Insurance deals with Islamic insurance and the law regulates both conventional and Islamic insurance. According to the provisions of this law, the conventional insurance companies which provide 10-year service in Islamic insurance should spin off the Islamic windows into Islamic insurance companies (Grant et al. 2017).

Islamic Microfinance is another major sector in Islamic finance and the Indonesian government has enacted Law No. 1 of 2013 on Microfinance institutions. Microfinance institutions may be either conventional or Sharia transactions and that can be established and owned by Indonesian individuals or entities (Grant et al. 2017).

In developing the Islamic financial system, Indonesia has adopted the regulations of Islamic Financial Services Board (IFSB), the Accounting and Auditing Organisation for Islamic Financial Institutions (AAOIFI) and various fatwa of OIC Fiqh Academy in Jeddah. Indonesia was also a member of the International Islamic Financial Market (IIFM), the International Islamic Liquidity Management Corporation (IILM) Islamic Development Bank (IDB), and the Islamic Financial Services Board (IFSB) (Furqani 2017).

\footnotetext{
${ }^{\circ}$ Copyright by Pusat Riset dan Pengembangan Produk Halal Journal of Halal Product and Research
} E-ISSN: 2654-9778; P-ISSN: 2654-9409 


\section{CONCLUSION}

The central banks of Indonesia and Malaysia have full authority to enact required laws and policy and to regulate the Islamic financial institutions in Indonesia and Malaysia. The Islamic financial institutions are regulated in accordance with the Sharia principles. Both the countries maintain a dual system of regulatory framework which considers the conventional and Islamic financial system. The countries should adopt the regulatory framework considering the socio-political conditions of the economy. In a country which is high in Muslim population can adopt fully Islamic framework, if there are different religions then country should adopt the framework according to the needs of the public. The growth and development of the country depends on the financial strategies that country adopts. Pakistan has shifted from fully Islamic regulatory system to dual system as it is required for the modern competitive world.

Even though the Islamic finance and Islamic financial institutions have evolved into a global concept, the growth has limited to the ambit of religion. The general public has view that the Islamic finance or allied services are mainly focussing on the Muslims and non-Muslims does not have a proper knowledge on the same. They are doubtful on the credibility of Islamic financial institutions and of Sharia law in country where conventional financial systems and domestic law operate. The countries should maintain a regulatory framework which incorporates Sharia principles into the legal system covering all requirements. The Islamic Financial Service Act 2013 (IFSA) enacted by Malaysia good example of incorporating the Sharia law into general legal structure. With this Act, Malaysia provides a complete framework for the Islamic financial institutions safeguarding the financial stability and effective functioning of the institutions. An effective legal framework can create a confidence on investors and it reduces the abuses which affects the stability of financial relations. The regulatory framework of the Islamic finance need to be more advanced filling the gaps to ensure stability and proper development.

\section{BIBLIOGRAPHY}

Alam N, Gupta L, Shanmugam B. 2017. Islamic Finance: A Practical Perspective. Palgrave Macmillan (UK)

Ayub M. 2007. Understanding Islamic Finance. John Wiley \& Sons (UK)

Bello S, Zubaedy AG. 2015. 'Sharī'ah Governance Framework Model for Malaysian Islamic Banking and Finance: A Critical Analysis' (2015) 17 (10) IOSR Journal of Business and Management <http://www.iosrjournals.org/iosr-jbm/papers/Vol17-issue10/Version1/B0171010919.pdf> accessed 28 Oct 2018.

Elasrag H. 2014. Corporate Governance in Islamic Finance: Basic Concepts and Issues (May 26, 2014) <http://dx.doi.org/10.2139/ssrn.2442014> accessed 27 Oct 2019.

Furqani H, 2017. 'The current situation of Islamic Economics in Indonesia' (ikam.org, December 2017) $<$ http://www.ikam.org.tr/en/sites/default/files/publication/pdf/the-current-situation-of-islamiceconomics-in-indonesia-pdf-ikam.pdf> accessed 28 October 2019.

Gearen S. 2009. Islamic Finance: Malaysia's Growing Role. Federal Reserve Bank of San Francisco Asia Focus, July 2009. <https://www.frbsf.org/banking/files/AF-Islamic-Finance-MalaysiasGrowing-Role-Jul09.pdf> accessed 26 Oct 2019.

Ginena K, Hamid A. 2015. Foundations of Sharia Governance of Islamic Banks. John Wiley \& Sons (UK)

Grant CR, Pradata NE, Muljosantoso R. 2017. Islamic Finance and Markets - Indonesia' (gettingthedealthrough.com, September 2017) <https://gettingthedealthrough.com/area/58/jurisdiction/42/islamic-finance-markets indonesia/> accessed 28 Oct 2019.

Hasan Z. 2010. Regulatory framework of sharia governance system in Malaysia, GCC Countries and the UK. Kyoto Bulletin of Islamic Area Studies (3): 2 <https://ssrn.com/abstract=2196825> accessed 25 Oct 2019.

Hassana R, Hussain MA. 2013. Scrutinizing the Malaysian regulatory framework on sharia advisors for Islamic financial institutions. Journal of Islamic Finance (2): 1. $<$ http://journals.iium.edu.my/iiibf-journal/index.php/jif/article/view/10> accessed 25 Oct 2019.

Hussain A, Williams N, 'Islamic Finance in Indonesia' (clydeco.com, 15 June 2016) $<$ https://www.clydeco.com/insight/article/islamic-finance-in-indonesia> accessed 28 October 2019. 
[IILM] International Islamic Liquidity Management Corporation - about us' (iilm.com) $<$ http://www.iilm.com/about-us/> accessed 27 October 2019.

Indonesia Legislations

Banking Act (Law 7 of 1992)

Zakat Act (Law No. 38 of 1999)

Limited Liability Companies Law (Law No. 40 of 2007)

Islamic Sovereign Bond (Sukuk) Act (Law No. 19 of 2008)

Sharia Banking Act (Law 21 of 2008)

Microfinance institutions Law (Law No. 1 of 2013)

Insurance Law (Law No. 40 of 2014)

[Investopedia]. 2019. Islamic Financial Service Board - IFSB' (investopedia.com) <https://www.investopedia.com/terms/i/ifsb.asp> accessed 27 October 2019.

[Islamic Finance Wiki]. Islamic International Rating Agency (wiki.islamic.finance.de) $<$ http://wiki.islamicfinance.de/index.php/International_Islamic_Rating_Agency> accessed 27 Oct 2019.

Kasim N, NuHtay S, Salman SA. 2013. Comparative analysis on AAOIFI, IFSB and BNM sharia governance guidelines. International Journal of Business and Social Science (4): 15

$<$ https://www.researchgate.net/publication/318654177_Comparative_Analysis on_AAOIFI_IFSB_and_BNM_Shari\%27ah_Governance_Guidelines> accessed 25 Oct 2019.

Kepli Z, Yazid M, 2013. The Legal and Regulatory Framework (Blogger, June 2013) <http://what-isislamic-finance.blogspot.com/2013/06/the-legal-and-regulatory-framework.html> accessed 27 Oct 2019.

Khan A and others, 'A Comparative Analysis of Regulatory and Supervisory Islamic Banking: Evidence from Pakistan, Malaysia, Bahrain, and the UK' (2015) 6 (6) Mediterranean Journal of Social Sciences <http://www.mcser.org/journal/index.php/mjss/article/view/8139> accessed 23 October 2019.

Kunhibava S. 2012. Islamic Banking in Malaysia. International Journal of Legal Information 40 <https://www.researchgate.net/publication/274961364_Islamic_Banking_in_Malaysia> accessed 26 Oct 2019.

Malaysia Legislations

Companies Act 1965

Islamic Banking Act 1983

Government Funding Act 1983

Takaful Act 1984

Banking and Financial Institutions Act 1989

Securities Commission Act 1993

Labuan Financial Services Authority Act 1996

Capital Market and Services Act 2007

Central Bank of Malaysia Act 2009

Islamic Financial Services Act 2013

Financial Services Act 2013

Sequerah $F$ and Hong J,2017. Islamic Finance and Market - Malaysia' (gettingthedealthrough.com, September 2017) <https://gettingthedealthrough.com/area/58/jurisdiction/55/islamic-finance-markets-malaysia/> accessed 28 Oct 2019.

Siregar MES. 2013. Banking regulatory framework and Islamic bank performance: a comparison between Indonesia and Malaysia. Prosiding Perkem VIII, JILID 2. <http://www.ukm.my/fep/perkem/pdf/perkemVIII/PKEM2013_3A5.pdf> accessed 24 Oct 2019.

Yussof SA. 2013. The Islamic financial services act, 2013: Malaysia's model framework for shariacompliance and stability. Islam and Civilizational Renewal Journal (3): 4 <http://www.iais.org.my/icr/index.php/icr/article/view/335> accessed 27 Oct 2019. 